\title{
Grundtvigs fadervor, Daniel for løverne, en skotsk hofprædikant på dansk og sognekirken som medskaber
}

I dette nummer kommer vi vidt omkring i teologiens emnefelter. Det første bidrag er anden del af Nils Arne Pedersens dobbeltartikel om Fadervor og dåb hos Grundtvig og betydningen heraf for liturgihistorien. Pedersen undersøger Grundtvigs brug af Det Nye Testamente, særligt Johannesevangeliet og Paulus, til at belyse forståelsen af dåben som "børnekår" hos Gud. Emnet belyses gennem en analyse af de steder i Johannesevangeliet og hos Paulus, der taler om Guds børn og om "børnekår" eller adoption. Særligt vigtig er "Abba! Fader" i Rom 8,15; Gal 4,6, som Grundtvig identificerede med Fadervor og opfattede som et "mundsord", der blev givet i dåben. Dette syn på Fadervor viser sig som den sandsynlige baggrund for flytningen af Fadervor til efter dåben i 1912-ritualet.

Frederik Poulsen leverer i nummerets anden artikel en litterær analyse af fortællingerne i Daniels Bog (Dan 1-6). Synsvinklen er, at disse fortællinger afspejler en diaspora-tilværelse, hvor man som etnisk og religiøst mindretal befinder sig i et spændingsfelt mellem to verdener. Poulsen understreger det spændings- og modsætningsfyldte i fortællingerne og viser, at diasporatilværelsens spænding mellem hjemlandet og værtslandet også spejler spændingen mellem jordisk og himmelsk virkelighed i Danielsbogens anden del.

Det tredje bidrag er en artikel af Carsten Bach-Nielsen om historien bag den danske udgivelse fra 1857 af den skotske præst John Cairds prædiken om kristendom i dagliglivet. Cairds prædiken, der var blevet udgivet på dronning Victorias og prins Alberts foranledning, blev oversat til tysk af C.K.J. von Bunsen, og siden til dansk af W. Hjort. Den danske udgave fik ingen videre udbredelse; men Bach-Nielsen peger på, hvordan tematiseringen af dagligliv og arbejde også må forstås med industrialiseringen som tidshistorisk baggrund.

Lars Buch Viftrup beskæftiger sig i den fjerde og sidste artikel med lokalt samarbejde imellem kirkesogne og kommuner i lyset af ideen om "samskabelse" ("co-creation" eller "co-production"), som har vundet indpas i nyere teori om offentlig forvaltning. Artiklen tager afsæt i en empirisk undersøgelse fra Aarhus, hvor tre grupper, repræsenterende kommunen, kirken og civilsamfundet mødtes i en række workshops i to faser (en inspirations- og en idégenereringsfase) for at 
udforske ideer om by og kirke og finde frem til projekter, der kunne være med til at løse fælles problemstillinger. Undersøgelsen sættes ind i et teologisk perspektiv med inddragelse af bl.a. Augustins og Luthers kirkeforståelse.

Jesper Høgenhaven 